\title{
Learning Process during Covid-19 Pandemic from Various Variables in Senior High School
}

\author{
Mila Noviana ${ }^{1}$, Sukardi Sukardi ${ }^{2}$, Ni Made Novi Suryanti ${ }^{2}$ \\ ${ }^{1}$ Sociology Education, The Faculty of Teacher Training and Education, University of Mataram, \\ Mataram, Indonesia \\ ${ }^{2}$ The Faculty of Teacher Training and Education \& Postgraduate, University of Mataram, \\ Mataram, Indonesia
}

\begin{abstract}
This study aimed to determine differences in the learning process during Covid-19 pandemic from various variables (gender, age, class, school location, school status) in Senior High Schools (SMA). This research used a quantitative approach with a survey method. The population in this study was all public and private high school students in Central Lombok Regency. The sampling technique was accidental sampling with a sample of 456 . The learning process data were collected using a questionnaire which already met research requirements in the google form. Overall data were analyzed quantitatively using non-parametric comparative analysis because the data was not normally distributed. The results showed the significant differences in the learning process during the Covid-19 pandemic from various variables (gender p-value 0.015 ; age p-value 0.041 ; class p-value 0.034 ; school location p-value 0.000 ; school status p-value $0.001)$ with $5 \%$ significance.
\end{abstract}

The better perception of the learning process during the pandemic was found in female, 16 years old, $10^{\text {th }}$ grader, public school, and urban school students.

DOI: $10.18421 /$ SAR34-03

https://doi.org/10.18421/SAR34-03

Corresponding author: Sukardi Sukardi,

The Faculty of Teacher Training and Education \& Postgraduate, University of Mataram, Mataram, Indonesia.

Email: sukardi@unram.ac.id

Received: 30 October 2020.

Revised: 15 December 2020.

Accepted: 21 December 2020.

Published: 30 December 2020.

(cc) BY-Nc-ND@ 2020 Mila Noviana, Sukardi Sukardi \& Ni Made Novi Suryanti; published by UIKTEN. This work is licensed under the Creative Commons AttributionNonCommercial-NoDerivs 3.0 License.

The article is published with Open Access at www.sarjournal.com
Therefore, the learning process during the Covid-19 pandemic should consider geographical characteristics (gender, age, class, school location, school status) in designing learning intervention.

Keywords - Learning Process; Covid-19 Pandemic

\section{Introduction}

The presence of Covid-19 pandemic had shifted our learning process from face-to-face learning, to online learning. However, learning process during this pandemic did not run very well. The research of Purwanto et al. [1] stated that not all teachers were proficient in using internet technology in some locations. Other problems include: 1) teachers that only focus on giving assignments without explaining the subject first [2]; 2) students starting to experience online learning boredom [3]; 3) online learning requiring a lot of money [4]; and 4) different regional conditions [5]. This could become a hindrance during online learning process. Therefore, it is important to deal with it so that the learning process during Covid-19 pandemic runs well.

Several previous studies found that online learning process during the pandemic, if implemented properly, could: 1) improve meaningful learning experiences because they had flexible learning time [6]; 2) improve independent learning [7]; 3) increase students' freedom to ask questions and express opinions [8]; and 4) increase students activity [6]. However, a different result was found by Dube [9] in rural areas with limited internet access, it was difficult to attend online learning. This is particularly in areas that were categorized as marginal with all infrastructure limitations [10].

Differences in regional conditions could affect online learning process during Covid-19 pandemic. Therefore, it is important to look at the differences in geographical characteristics, such as gender [11], age [12], class [13], school location [14], and school status [15]. This learning process is very interesting to study since it is conducted during Covid-19 period. Even before the pandemic, the service 
quality was still problematic [16]. Based on these differences, the novelty of this research lies in the variables (gender, age, class, school location, school status) that affect online learning process during Covid-19 pandemic. Thus, the purpose of this study is to determine the differences in the learning process during Covid-19 pandemic from various variables (gender, age, class, school location, school status) in Senior High Schools (SMA).

\section{Research Method}

This research used quantitative approach with survey method. The survey method involved a systematic, in-depth, and comprehensive information analysis [17]. The survey quantitatively described some trends, behaviors, or opinions of a population by examining a sample of mentioned population. The population in this study was all public and private high school students in Central Lombok Regency with a total of 13.626 [18]. Therefore, the sampling technique used is accidental sampling technique. Using the Slovin formula, the minimum sample was 389. There are a total of 456 respondents who filled out the questionnaire; as many as 178 respondents are male, while the other 278 respondents are female.

This study used questionnaire as data collection technique, which was adapted from Socha and Sigler's [19] learning process questionnaire with motivation and strategy indicators. All instruments used 5 point Likert scale $(1=$ strongly disagree to $5=$ strongly agree). Furthermore, the validity of the instruments was tested using Pearson productmoment correlation coefficient (r); all 24 items are regarded as valid. The instruments were then put through a reliability test using the Alpha Cronbach formula, from which test the correlation coefficient value of 0.921 with very high criteria was obtained.

The learning process data were analyzed using descriptive statistics. The analysis prerequisite test used Levene statistical test for homogeneity and Kolmogorov-Smirnov test for normality. Hypothesis testing in this study used non-parametric comparative analysis because the data was not normally distributed. The overall analysis used SPSS program version 22.00 for windows.

\section{Results}

\section{Descriptive Statistics}

The table below shows a descriptive statistic of the learning process from various variables.
Table 1. Result of Descriptive Statistics

\begin{tabular}{lccccc}
\hline Variables & N & Min & Max & Mean & Std. \\
\hline Gender & & & & & \\
Male & 178 & 50 & 101 & 77.52 & 11.992 \\
Female & 278 & 35 & 104 & 79.53 & 12.961 \\
Age & & & & & \\
16 year old & 179 & 35 & 102 & 80.58 & 12.673 \\
17 year old & 195 & 42 & 104 & 78.57 & 12.738 \\
18 year old & 82 & 43 & 101 & 75.12 & 11.481 \\
Class & & & & & \\
X $\left(10^{\text {th }}\right)$ & 139 & 35 & 104 & 80.40 & 13.014 \\
XI $\left(11^{\text {th }}\right)$ & 173 & 50 & 102 & 80.25 & 11.818 \\
XII $\left(12^{\text {th }}\right)$ & 144 & 42 & 102 & 75.32 & 12.562 \\
School & & & & & \\
Locations & & & & & \\
Remote & 57 & 43 & 99 & 73.91 & 12.070 \\
Rural & 103 & 45 & 104 & 76.09 & 11.633 \\
Urban & 296 & 35 & 102 & 80.59 & 12.675 \\
School & & & & & \\
Status & & & & & \\
Public & 424 & 35 & 104 & 79.23 & 12.497 \\
Private & 32 & 51 & 98 & 72.25 & 12.585 \\
\hline
\end{tabular}

\section{Analysis Prerequisite Test Results}

The analysis prerequisite tests in this study were conducted through normality and homogeneity test. Here, Kolmogorov-Smirnov was used for the normality test, while Levene statistic was used for the homogeneity test. The result was shown in the Table below.

Table 2. Result of Normality Test

\begin{tabular}{lccc}
\hline Variable & Sig. & A & Explanation \\
\hline Learning Process & 0.000 & 0.05 & Not normal \\
\hline
\end{tabular}

The normality test shows the probability of $0.000<$ 0.05 . Thus, it can be concluded that the sample for the data that is sociology subject learning process during Covid-19 pandemic, originated from a population that is not distributed normally. Therefore, the homogeneity test in this study was not carried out.

\section{Hypothesis Tests}

The analysis prerequisite test shows that the data was not distributed normally. Hence, hypothesis testing was conducted using non-parametric comparative analyses, Mann-Whitney test, and Kruskal-Wallis test. The results were shown in the Table below. 
Table 3. Result of Hypothesis Tests

\begin{tabular}{|c|c|c|c|c|c|c|c|}
\hline 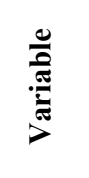 & 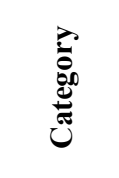 & Z & $\sum_{\Sigma}^{\bar{E}}$ & $\sum$ & 递 & 8 & \\
\hline \multirow{2}{*}{$\begin{array}{l}\dot{\bar{v}} \\
\overline{0} \\
\dot{0}\end{array}$} & Male & 178 & 77.52 & \multirow[b]{2}{*}{-2.42} & \multirow[b]{2}{*}{0.015} & \multirow[b]{2}{*}{0.05} & \multirow[b]{2}{*}{$\begin{array}{c}\mathrm{H}_{0} \\
\text { Rejected }\end{array}$} \\
\hline & Female & 278 & 79.53 & & & & \\
\hline \multirow{3}{*}{$\stackrel{8}{<}$} & $\begin{array}{c}16 \\
\text { years }\end{array}$ & 179 & 80.58 & \multirow{3}{*}{14.26} & \multirow{3}{*}{0.041} & \multirow{3}{*}{0.05} & \multirow{3}{*}{$\begin{array}{c}\mathrm{H}_{0} \\
\text { Rejected }\end{array}$} \\
\hline & $\begin{array}{l}17 \\
\text { years }\end{array}$ & 195 & 78.57 & & & & \\
\hline & $\begin{array}{c}18 \\
\text { years }\end{array}$ & 82 & 75.12 & & & & \\
\hline \multirow{3}{*}{$\begin{array}{l}0 \\
0 \\
0 \\
0\end{array}$} & $\underset{\left(10^{\text {th }}\right)}{X}$ & 139 & 80.40 & \multirow{3}{*}{13.77} & \multirow{3}{*}{0.034} & \multirow{3}{*}{0.05} & \multirow{3}{*}{$\begin{array}{c}\mathrm{H}_{0} \\
\text { Rejected }\end{array}$} \\
\hline & $\begin{array}{c}\mathrm{XI} \\
\left(11^{\text {th }}\right)\end{array}$ & 173 & 80.25 & & & & \\
\hline & $\begin{array}{c}\text { XII } \\
\left(12^{\text {th }}\right)\end{array}$ & 144 & 75.32 & & & & \\
\hline \multirow{3}{*}{ 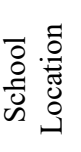 } & Urban & 296 & 80.59 & \multirow{3}{*}{20.97} & \multirow{3}{*}{0.000} & \multirow{3}{*}{0.05} & \multirow{3}{*}{$\begin{array}{c}\mathrm{H}_{0} \\
\text { Rejected }\end{array}$} \\
\hline & Rural & 103 & 76.09 & & & & \\
\hline & Remote & 57 & 73.91 & & & & \\
\hline \multirow{2}{*}{ 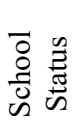 } & Public & 424 & 79.23 & \multirow[b]{2}{*}{-3.28} & \multirow[b]{2}{*}{0.001} & \multirow[b]{2}{*}{0.05} & \multirow{2}{*}{$\begin{array}{c}\mathrm{H}_{0} \\
\text { Rejected }\end{array}$} \\
\hline & Private & 32 & 72.25 & & & & \\
\hline
\end{tabular}

The summary shown in Table 3 can be explained as follows:

H1: It was assumed that there are differences in the perceptions regarding the learning process during Covid-19 pandemic in senior high schools that are based on gender. Based on the results of the test using SPSS, a 2.426 Mann-Whitney test value with the probability of $0.015<0.05$ was obtained. Based on these results, it can be concluded that there are differences in the perceptions regarding the learning process during Covid-19 pandemic between males and females. This difference is considered significant rooted in its probability value.

$\mathrm{H} 2$ : It was assumed that there are differences in the perceptions regarding the learning process during Covid-19 pandemic in senior high schools that are based on age. Based on the results of the test using SPSS and Kruskal-Wallis test, a 14.262 value with the probability of $0.041<0.05$ was obtained. Based on these results, it can be concluded that there are differences in the perceptions of 16 year olds, 17 year olds, and 18 year olds regarding the learning process during Covid-19 pandemic. This difference is considered significant according to its probability value.

H3: It was assumed that there are differences in the perceptions regarding the learning process during Covid-19 pandemic in senior high schools that are based on class. Based on the the Kruskal-Wallis test results using SPSS, a value of 13.771 with the probability of $0.034<0.05$ was obtained. Based on these results, it can be concluded that there are differences in the perceptions regarding the learning process during Covid-19 pandemic among classes of X (ten), XI (eleven), and XII (twelve) graders. This difference is considered significant based on its probability value.

H4: It was assumed that there are differences in the perceptions regarding the learning process during Covid-19 pandemic in senior high schools that are based on school locations. After conducting KruskalWallis test results using SPSS, a value of 20.077 with a probability of $0.000<0.05$ was obtained. Based on these results, it can be concluded that there are differences in the perceptions that are based on the location of schools (urban, rural, and remote areas) which affect the learning process during the Covid19 pandemic. This difference is considered significant according to its probability value.

H5: It was assumed that there are differences in the perceptions regarding the learning process during this pandemic in senior high schools that are based on the school status. After conducting Mann-Whitney U test using SPSS, a u value of -3.282 was obtained, with a probability value of $0.001<0.05$. Based on these results, it can be concluded that schools that are of a different status (public or private) have different perceptions, which affect the learning process during Covid-19 pandemic. This difference is considered significant based on its probability value.

Based on the results of these hypotheses, it can be concluded that there are differences in the perceptions regarding learning process during Covid19 pandemic from various variables (gender, age, class, school location, school status) in senior high school.

\section{Discussion}

The results showed that there were differences in the learning process during Covid-19 pandemic from various variables (gender, age, class, school location, and school status) in senior high schools. The results showed that there were differences in the learning process during the pandemic based on gender. The results of this study confirmed Zeyer's previous study [20] that stated "There are differences between men and women in learning styles that affect thinking skills...". Furthermore, the study found that there is a tendency for female students to have better perceptions of the learning process during the pandemic, compared to male students. The results of this study were supported by Gregory [11] who stated that female students were better than male students during online learning process. This was because female students were more aware of the learning strategies used [21], were more motivated 
[22], had better abilities in time management, independent learning, and exerted more effort while studying [23], and had better performance [24]. Meanwhile, male students were worse in learning because they devote less time and energy to study [25]. Hence, females had better learning achievement [26] and problem solving skill [24] compared to males. On the contrary, different studies showed that men use left brain more: in thinking logically and innovatively, empowering creative thinking skills [26].

The results of age variable showed that there are differences in learning process during the pandemic based on age. This result was supported by previous research by Becirovic and Huric-Becirovic [12] which stated that there was a significant difference in learning motivation based on age. In that study, it was found that 18 years old students had lower learning motivation, thus affecting the learning process. Similarly, this study also discovered that 16 and 17 years old students tend to have better perceptions of the learning process during the pandemic, compared to 18 years old students. This was due to environmental influences, biological changes, or puberty [25]. At the start of young adulthood, 18 to 29 years old, there is a decrease in cognitive function, especially in associative memory (the ability to learn and memorize relationships between unrelated things), which affects a person's learning ability [27].

The results of class variable showed that there are differences in the learning process during the pandemic period based on class. The results of this study are confirmed by Nayir [13] which found that there was a significant difference in the involvement of students in the learning process based on class due to changes in motivation as the grade level increased. This difference in motivation affected the involvement of students. Similarly, this study also shows that $10^{\text {th }}$ graders' and $11^{\text {th }}$ graders' perception were better than those of the $12^{\text {th }}$ graders. This was because $10^{\text {th }}$ grade students have intrinsic motivation such as a strong interest in learning, so they do not easily give up when facing challenges [28]. On the contrary, $12^{\text {th }}$ graders focus more on university admission tests [13], and have higher extrinsic motivation. Hence, they tend to do what was needed and sometimes refuse to participate in classroom activities [29]. This is considering that "learning outside the classroom can avoid a feeling of saturation, boredom, and the perception that "learning is only conducted inside a classroom." [30].

The results of the school location variable showed that there are differences in the learning process during the pandemic period based on school locations. The results of this study were confirmed by a study by Owoeye and Yara [14], which discovered that there was a significant difference between learning achievement of urban and rural school students. Similarly, this study also discovered that the learning process in urban and rural schools is better than that in remote schools. These results are in line with Wang [31], which stated that schools in remote areas had limitations when it comes to availability of access to technology, unstable internet network. In addition, the teachers and students have lower computer literacy skills than the teachers and students in urban schools. Besides, as well as the lack of resources and infrastructure played an important role. Furthermore, Ogbugo-Ololube [32] said that remote schools face the challenges of poverty, funding levels, and geographical conditions, all of which had an impact on the quality of learning received by students.

The results of school status variables showed that there were differences in the learning process during the pandemic based on school status. Public school students have better perception regarding the learning process compared to their friends in private schools. This result was similar to Mulyanti et al. [33], which found that there were differences in the learning process based on school status. In this study, it was discovered that public schools were better than other schools when it comes to availability of facilities, so the learning process during the pandemic could go well. In line with this, Humairo [34] stated that public schools were different in terms of teaching patterns, programs and curricula, learning methods, quality of outputs, and facilities, which affected the learning process. However, the results of a different study by Horrowitz and Spector [35] stated that the learning process in private schools was better than that in public schools in terms of academic performance.

\section{Conclusions and Implications}

Based on the results of data analysis and discussion that have been conducted, it can be concluded that there are differences in the learning process during Covid-19 pandemic from various variables (gender, age, class, school locations, and school status) in senior high school. Overall, in senior high school, perceptions regarding the learning process during this pandemic tend to be better in students who: 1) are females; 2) are 16 years old; 3) are still in $10^{\text {th }}$ grade; 4) go to public schools; and 5) go to urban schools. This is compared to their fellow students who: 1) are males; 2) are 17 and 18 years old; 3) are in $11^{\text {th }}$ and $12^{\text {th }}$ grade; 4) go to private schools; and 5) go to schools in rural and remote areas. Through the results of this study, it is concluded that the learning process during Covid-19 pandemic should consider geographical characteristics (gender, age, class, school location, and school status) in designing learning interventions. 


\section{References}

[1]. Purwanto, A., Pramono, R., Asbari, M., Hyun, C. C., Wijayanti, L. M., \& Putri, R. S. (2020). Studi Eksploratif Dampak Pandemi COVID-19 Terhadap Proses Pembelajaran Online di Sekolah Dasar. EduPsyCouns: Journal of Education, Psychology and Counseling, 2(1), 1-12.

[2]. Allo, M. D. G. (2020). Is the online learning good in the midst of Covid-19 Pandemic? The case of EFL learners. Jurnal Sinestesia, 10(1), 1-10.

[3]. Irawan, A. W., Dwisona, D., \& Lestari, M. (2020). Psychological Impacts of Students on Online Learning During the Pandemic COVID19. KONSELI: Jurnal Bimbingan dan Konseling (EJournal), 7(1), 53-60. http://doi.org/10.0/kons.v7i1.6389

[4]. Morgan, H. (2020). Best Practices for Implementing Remote Learning during a Pandemic. The Clearing House: A Journal of Educational Strategies, Issues and Ideas, 93(3), 135-141. https://doi.org/10.1080/00098655.2020.1751480

[5]. Alea, L. A., Fabrea, M. F., Roldan, R. D. A., \& Farooqi, A. Z. (2020). Teachers' Covid-19 awareness, distance learning education experiences and perceptions towards institutional readiness and challenges. International Journal of Learning, Teaching and Educational Research, 19(6), 127-144. http://doi.org/10.26803/ijlter.19.6.8

[6]. Mukhtar, K., Javed, K., Arooj, M., \& Sethi, A. (2020). Advantages, Limitations and Recommendations for online learning during COVID19 pandemic era. Pakistan Journal of Medical Sciences, 36(COVID19-S4).

https://doi.org/10.12669/pjms.36.COVID19-S4.2785

[7]. Soni, V. D. (2020). Global Impact of E-learning during COVID 19. Available at SSRN 3630073. http://doi.org/10.2139/ssrn.3630073

[8]. Firman, F., \& Rahayu, S. (2020). Pembelajaran Online di Tengah Pandemi Covid-19. Indonesian Journal of Educational Science (IJES), 2(2), 81-89.

[9]. Dube, B. (2020). Rural online learning in the context of COVID 19 in South Africa: Evoking an inclusive education approach. Multidisciplinary Journal of Educational Research, 10(2), 135-157. http://doi.org/10.447/remie.2020.5607

[10]. Sukardi, S., Ismail, M., Suryanti, N., \& Made, N. (2014). Model Pendidikan Kewirausahaan Berbasis Keterampilan Lokalbagi Anak Putus Sekolah pada Masyarakat Marginal. Cakrawala Pendidikan, (3), 84826. Doi: $10.21831 /$ cp.v3i3.2384

[11]. Gregory, C. B., \& Lampley, J. H. (2016). Community College Student Success in Online versus Equivalent Face-to-Face Courses. Journal of Learning in Higher Education, 12(2), 63-72.

[12]. Bećirović, S., \& Hurić-Bećirović, R. (2017). The role of age in students' motivation and achievement in learning English as a second language. The Journal of Linguistic and Intercultural Education, 10(1), 23. http://doi.org/10.29302/jolie.2017.10.1.2
[13]. Nayir, F. (2017). The Relationship between Student Motivation and Class Engagement Levels. Eurasian Journal of Educational Research, 71, 59-77. http://doi.org/10.14689/ejer.2017.71.4

[14]. Owoeye, J. S., \& Olatunde Yara, P. (2011). School facilities and academic achievement of secondary school agricultural science in Ekiti State, Nigeria. Asian social science, 7(7), 64-74.

Doi: 10.5539/ass.v7n7p64

[15]. Shabbir, M., Wei, S., Fu, Y., Chong, R., Marwat, M. A., Nabi, G., \& Ahmed, B. (2014). A comparative study of public versus private primary schools: An evidence from Azad Kashmir (Pakistanoccupied Kashmir). Journal of Education and Practice, 5, 154168.

[16]. Sukardi, S., Rusdiawan, R., \& Wardana, L. (2019). The Competitiveness of Master of Education Graduates: Porter's Diamond Analysis. International Journal of Emerging Technologies in Learning (iJET), 14(19), 179-187. https://doi.org/10.3991/ijet.v14i19.10767

[17]. Ary, D., Jacobs, L. C., Sorensen, C., \& Razavieh, A. (2010). Introduction to research in education eight edition. Wadsworth: Cengage Learning.

[18]. Kementerian Pendidikan dan Kebudayaan. (2019). Laporan Jumlah Peserta Didik Siswa Menengah Atas tahun 2019. Lombok Tengah.

Retrieved from: http://dp2m.umm.ac.id/files/file/ICTLT-2014_2.pdf [accessed: 10 June 2020].

[19]. Socha, A., \& Sigler, E. A. (2012). Using multidimensional scaling to improve functionality of the Revised Learning Process Questionnaire. Assessment \& Evaluation in Higher Education, 37(4), 409-425.

http://doi.org/10.1080/02602938.2010.536835

[20]. Zeyer, A. (2018). Gender, complexity, and science for all: Systemizing and its impact on motivation to learn science for different science subjects. Journal of Research in Science Teaching, 55(2), 147-171. https://doi.org/10.1002/tea.21413

[21]. Mahmud, M., \& Nur, S. (2018). Exploring Students' Learning Strategies and Gender Differences in English Language Teaching. International Journal of Language Education, 2(1), 51-64. http://doi.org/10.26858/ijole.v2i1.346

[22]. Green-Demers, I., Legault, L., Pelletier, D., \& Pelletier, L. G. (2008). Factorial invariance of the Academic Amotivation Inventory (AAI) across gender and grade in a sample of Canadian high school students. Educational and Psychological Measurement, 68(5), 862-880. http://doi.org/10.1177/0013164407313368

[23]. Marrs, H., \& Sigler, E. A. (2012). Male academic performance in college: The possible role of study strategies. Psychology of Men \& Masculinity, 13(2), 227. http://doi.org/10.1037/a0022247

[24]. Perdana, R. (2019). Analysis of Student Critical and Creative Thinking (CCT) Skills on Chemistry: A Study of Gender Differences. Journal of Educational and Social Research, 9(4), 43-43.

http://doi.org/10.36941/jesr-2019-0006 
[25]. Hornjak, S. (2017). Uticaj uzrasta i pola na usvajanje stranog jezika. Komunikacija i kultura online, 1(1), 222-233.

[26]. Fuad, N. M., Zubaidah, S., Mahanal, S., \& Suarsini, E. (2017). Improving Junior High Schools' Critical Thinking Skills Based on Test Three Different Models of Learning. International Journal of Instruction, 10(1), 101-116.

[27]. Birdsong, D. (2006). Age and second language acquisition and processing: A selective overview. Language learning, 56, 9-49. https://doi.org/10.1111/j.1467-9922.2006.00353.x

[28]. Saeed, S., \& Zyngier, D. (2012). How motivation influences student engagement: a qualitative case study. Journal of Education and Learning, 1(2), 252267. http://doi.org/10.5539/jel.v1n2p252

[29]. Gibbs, R., \& Poskitt, J. (2010). Student engagement in the middle years of schooling (Years 7-10): A literature review report to the Ministry of Education. Retrieved from: www.educationcounts. govt.nz/publications [accessed: 17 May 2020].

[30]. Sukardi, S. (2016). Desain Model Prakarya dan Kewirausahaan Berbasis Ekonomi Kreatif Berdimensi Industri Keunggulan Lokal. Jurnal Cakrawala Pendidikan, 35(1).

Doi: https://doi.org/10.21831/cp.v1i1.8381
[31]. Wang, P. Y. (2013). Examining the Digital Divide between Rural and Urban Schools: Technology Availability, Teachers' Integration Level and Students' Perception. Journal of Curriculum and Teaching, 2(2), 127-139. Doi: 10.5430/jct.v2n2p127

[32]. Ogbugo-Ololube, R. (2016). Impact of students' parental background on academic achievement in secondary schools in Obio/Akpor LGA, Rivers State, Nigeria. International Journal of Scientific Research in Education, 9(2), 115-126.

[33]. Mulyanti, B., Purnama, W., \& Pawinanto, R. E. (2020). Distance learning in vocational high schools during the covid-19 pandemic in West Java province, Indonesia. Indonesian Journal of Science and Technology, 5(2). https://doi.org/10.17509/ijost.v5i2.24640

[34]. Dewi Humairo, Hafida. (2014). Perbedaan organizational citizenship behavior (OCB) pada guru sekolah menengah kejuruan (SMK) ditinjau dari status sekolah. Character: Jurnal Penelitian Psikologi., 2(2).

[35]. Horowitz, J. B., \& Spector, L. (2005). Is there a difference between private and public education on college performance?. Economics of Education Review, 24(2), 189-195. 